\title{
The planform of epeirogeny: vertical motions of Australia during the Cretaceous
}

\author{
Mark Russell and Michael Gurnis* \\ Department of Geological Sciences, The University of \\ Michigan, Ann Arbor, MI 48109-1063, USA
}

\begin{abstract}
Estimates of dynamic motion of Australia since the end of the Jurassic have been made by modelling marine flooding and comparing it with palaeogeographical reconstructions of marine inundation. First, sediment isopachs were backstripped from present-day topography. Dynamic motion was determined by the displacement needed to approximate observed flooding when allowance is made for changes in eustatic sea-level. The reconstructed inundation patterns suggest that during the Cretaceous, Australia remained a relatively stable platform, and flooding in the eastern interior during the Early Cretaceous was primarily the result of the regional tectonic motion. Vertical motion during the Cretaceous was much smaller than the movement since the end of the Cretaceous.

Subsidence and marine flooding in the Eromanga and Surat Basins, and the subsequent $500 \mathrm{~m}$ of uplift of the eastern portion of the basin, may have been driven by changes in plate dynamics during the Mesozoic. Convergence along the north-east edge of Australia between 200 and $100 \mathrm{Ma}$ coincides with platform sedimentation and subsidence within the Eromanga and Surat Basins. A major shift in the position of subduction at $140 \mathrm{Ma}$ was coeval with the marine incursion into the Eromanga. When subduction ended at $95 \mathrm{Ma}$, marine inundation of the Eromanga also ended. Subsidence and uplift of the eastern interior is consistent with dynamic models of subduction in which subsidence is generated when the dip angle of the slab decreases and uplift is generated when subduction terminates (i.e. the dynamic load vanishes). Since the end of the Cretaceous, Australia has uniformly subsided by about $250 \mathrm{~m}$ with little apparent tilting. This vertical subsidence may have resulted from the northward migration of the continent from a dynamic topography high and geoid low toward lower dynamic topography and a higher geoid.
\end{abstract}

\section{INTRODUCTION}

Epeirogenic motion, custatic sea-lcvel change and local tectonic motion are among factors which interact to produce the apparent sea-level change recorded in the distribution of marine sediments. Changes in apparent sea-level are roughly quantifiable from the extent of marine flooding inferred from the distribution of sediments but the dynamic processes causing these changes are not readily determined. Local tectonic motion will complicate any analysis by allowing flooding or uplift on a smaller scale unrelated to the large-scale influence of eustasy and epeirogeny. The effect of epeirogeny on apparent sea-level and the sedimentary record will be similar to the effect of true eustatic change. Determining the relative magnitude of each of these

\footnotetext{
* Present address: Seismological Laboratory, California Institute of Technology, Pasadena, CA 91125, USA.
}

factors on the sedimentary record and the pattern and extent of marine flooding is a problem requiring assumptions about either epeirogeny or eustasy.

The Cretaccous of Australia provides a possibly unique setting in which to investigate these problems. During the Cretaceous, the inundation of Australia and custatic curves are out of phase (Fig. 1). Maximum flooding of Australia occurred in the Late Aptian/Early Albian (Struckmeyer \& Brown, 1990) when large fractions of the eastern and southern craton and its margins experienced marine inundation. During the Late Cretaceous, Australia became progressively exposed, with a minimum in flooding occurring approximately when global sea-level was inferred to be near a maximum (Veevers, 1984; Struckmeyer \& Brown, 1990). A discrepancy also exists between the relative sea-level curves of the various basins in Australia. Sea-level curves for the western margin of Australia, in particular those for the Perth and Carnarvon Basins (Fig. 2), 


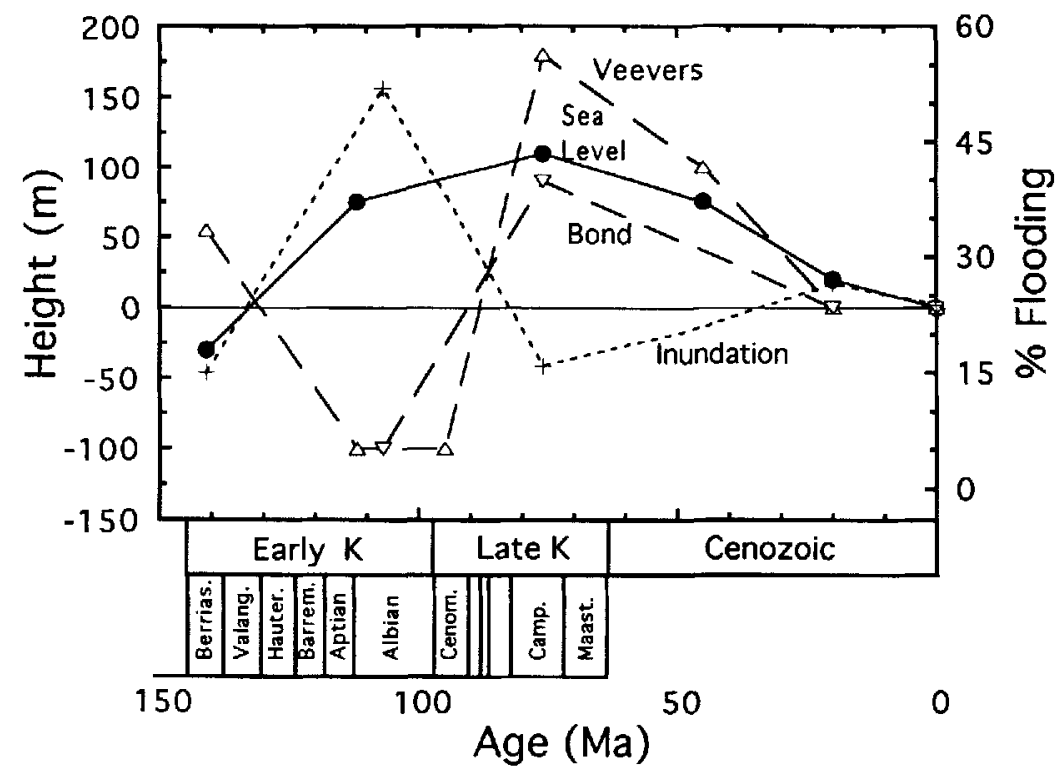

Fig. 1. Estimated change in mean continental height for Australia derived from hypsometric analysis by Bond (1978) and Veevers (1984), eustatic sea-level after Watts \& Steckler (1979), as modified by Veevers (1984), and the inundation curve for Australia uscd in the hypsometric analysis by Veevers (1984). Inundation curve is the percentage of continental area above $-200 \mathrm{~m}$ flooded. resemble the eustatic curve of Haq et al. (1987), while the sca-level curves inferred from other basins, most notably the Eromanga, correlate poorly with the Haq et al. curve (Struckmeyer \& Brown, 1990).

These apparently incongruous sea-level curves support the hypothesis that Australia experienced several episodes of possibly craton-wide vertical motion as well as local vertical movement during the Cretaccous (Bond,
1978; Veevers, 1984). Hypsometric analysis by Bond $(1978,1979)$ has been used in an effort to resolve these discrepancies. Bond used individual continental inunda tion curves and hypsometries to determine simultaneously eustatic variation and vertical continental motion without making unsupported assumptions about local subsidence rates or performing complex sedimentary analysis. Assuming constant continental hyp-

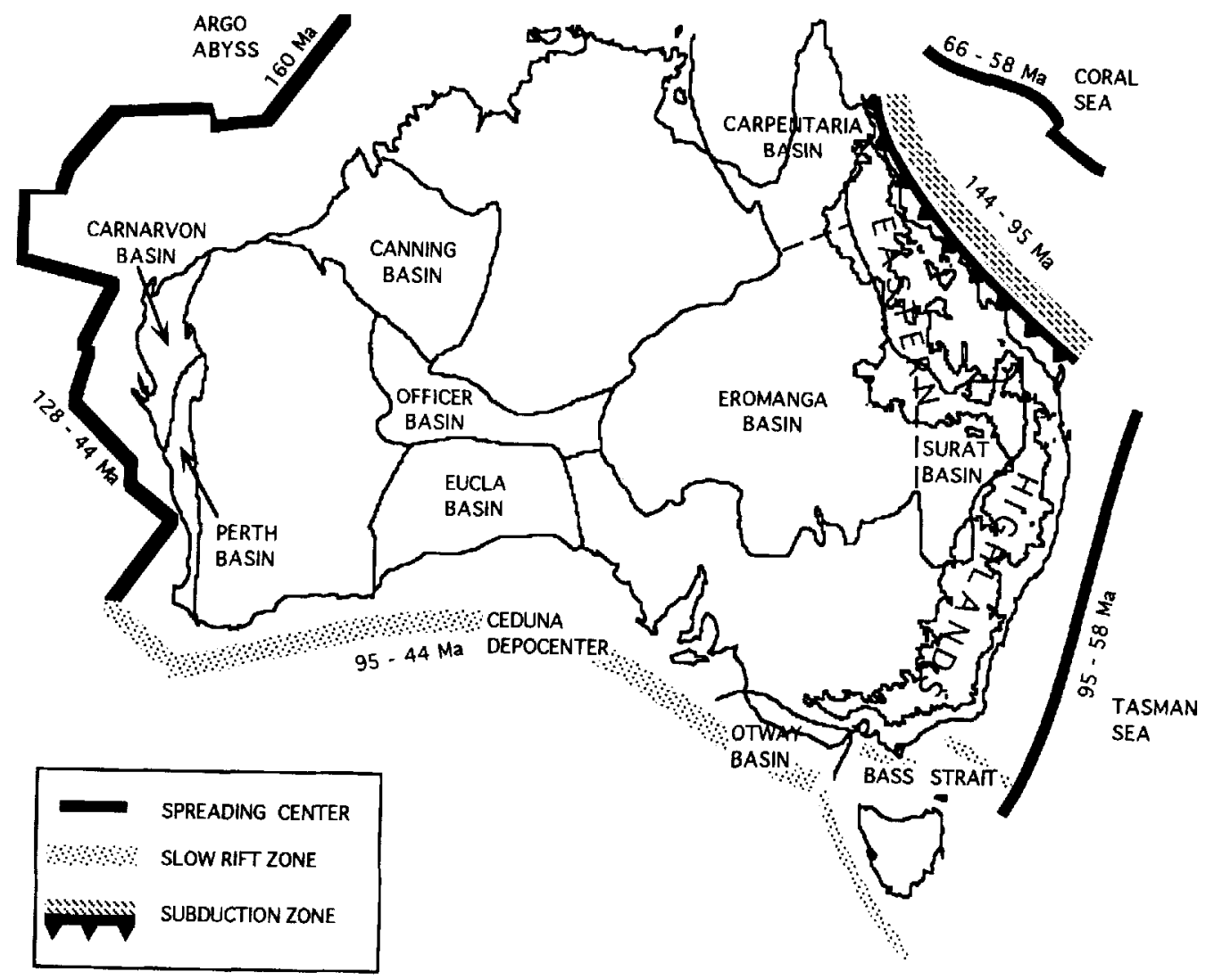

Fig. 2. Map of Australia showing the locations of major Mesozoic depocentres, the positions of rift zones and convergent margins active since the Mesozoic, and age interval over which they were active. 
sometry, the percentage of continental flooding from palaeogeographical reconstructions was used to calculate relative sea-levels for each continent. If the sea-level change obtained for all continents is equal then it is clearly eustatic; differences in sea-level determined for each continent imply differential vertical movement. By assigning vertical displacements to the continents to minimize sea-level discrepancies, Bond (1978) was able to estimate the magnitude of both eustasy and continental epeirogeny.

In this paper we estimate vertical motions of Australia by modelling marine flooding in planform. We use current Australian topography, modified by sediment unloading, and an inferred sea-level curve as a basis to model the patterns of marine inundation during the Cretaceous. By comparing our models with palaeogeographical reconstructions of Australia, we estimate the bulk vertical motions of Australia over the past $150 \mathrm{Myr}$ and attempt to define areas in which local tectonic motions affected the pattern of marine inundation. Moreover, we attempt to link the continent-wide vertical motion and regional tectonic motions to dynamic processes within the mantle. Indeed, dynamic topography (the pushing up and down of the Earth's surface in response to viscous stresses driven by internal buoyancy forces within the mantle; Richards \& Hager, 1984) may provide a simple explanation for the observed motions (Gurnis, 1992a).

\section{AUSTRALIA'S TECTONIC HISTORY}

The extent of marine inundation in Australia has been heavily influenced by changes in tectonic setting that have occurred in Australia since the Jurassic as a result of the break up of Gondwanaland. At about $160 \mathrm{Ma}$, separation into western Gondwanaland, composed of South America and Africa, and eastern Gondwanaland, which included Australia, India, Antarctica, the Lord Howe Rise/New Zealand Plateau and the Papuan Peninsula, was beginning. This was immediately followed by the fragmentation of eastern Gondwanaland, which would not be complete until $30 \mathrm{Ma}$ when the last vestige of the connection between Australia and Antarctica was severed south of Tasmania. Only a brief outline of Australia's history since the Jurassic will be presented here to give a spatial framework to our analysis. More complete descriptions can be found elsewhere (Falvey \& Mutter, 1981; Vecvers, 1984; Wellman, 1987; Veevers et al., 1991).

\section{Evolution of Australia's passive margins}

Fragmentation of Gondwanaland proceeded in a roughly anticlockwise direction beginning along the north-west coast about $160 \mathrm{Ma}$ when spreading began in the Argo Abyssal Plain (Fig. 2). Spreading continued south as India began to split away from Australia at about $128 \mathrm{Ma}$.
Splitting of east Gondwanaland proceeded anticlockwise as spreading began between Australia and Antarctica and between Australia and the Lord Howe Rise/New Zealand at about $95 \mathrm{Ma}$. This trend continued north as the Coral Sea opened as a back-arc basin beginning at about $66 \mathrm{Ma}$. Spreading stopped along Australia's eastern margin in both the Coral Sea and the Tasman Sea at $58 \mathrm{Ma}$. Significant change occurred about $44 \mathrm{Ma}$ when spreading ceased between Australia and India, and a change in spreading occurred between Australia and Antarctica. Between 95 and $44 \mathrm{Ma}$ spreading along the southern margin was slow, having a half spreading rate of $4.3 \mathrm{~mm} \mathrm{yr}^{-1}$; at about $44 \mathrm{Ma}$ the half spreading rate increased to $29 \mathrm{~mm} \mathrm{yr}^{-1}$, remaining at that rate since (Veevers, 1984).

\section{Convergent margins}

Of major importance to the tectonic development of Australia was the convergent margin that dominated the north-eastern plate boundary of Australia between 200 and $100 \mathrm{Ma}$. The exact position of the boundary is uncertain, but it appears likely that between 200 and $140 \mathrm{Ma}$ it lay several hundred kilometres off the present Queensland coast north of present-day $30^{\circ} \mathrm{S}$ (Veevers, 1984). The volcanic record of this time is confused by the subsequent spreading of the Coral Sea and the subsidence of its margins. At about $140 \mathrm{Ma}$ the boundary may have moved toward the craton as suggested by the movement of andesitic volcanism toward a position coincident with the present Queensland coast (Veevers, 1984). This configuration continued until $90 \mathrm{Ma}$ at which time the magmatic arc was replaced by continental rifting, continental breakup and the formation of the Coral Sea (Veevers, 1984).

\section{The eastern highlands}

The eastern highlands range in elevation from 300 to $1600 \mathrm{~m}$ and extend in a band about $400 \mathrm{~km}$ wide roughly parallel to the eastern margin of Australia. They are composed of two distinct morphologies that roughly coincide with the variation in tectonic boundaries observed during the Cretaceous. Areas north of $18^{\circ} \mathrm{S}$ and south of $26^{\circ} \mathrm{S}$ are asymmetrical, with the crest of the highlands about $100-150 \mathrm{~km}$ from the coast, and have a steep escarpment. The region between $18^{\circ} \mathrm{S}$ and $26^{\circ} \mathrm{S}$ is more symmetrical, with the crest extending inland for up to $400 \mathrm{~km}$ (Wellman 1987).

Timing of the uplift is constrained by the Mesozoic sediment cover, at present over one-quarter of the highlands. North of $26.5^{\circ} \mathrm{S}$ Early Cretaceous marine sediments extend beyond the crest of the highlands showing that much of this area was below sea-level in the Early Cretaceous, and was subsequently uplifted (Wellman, 1987). Uplift timing in the northern highlands is further constrained by the presence of large volumes of immature Aptian and Cenomanian sandstone in the 
Eromanga Basin which was derived from contemporaneous andesitic volcanics (Exon \& Senior, 1976). The closest active andesitic volcanism, at $c .111 \pm 5 \mathrm{Ma}$, is found offshore along the east coast of Quecnsland (Clarke et al., 1971). Deposition of scdiment derived from these volcanics in the Eromanga Basin requires transport across the region now occupied by the highlands. This suggests that the northern highlands were uplifted after the Mid Cretaceous. Jones \& Veevers (1983) suggest that uplift may have initiated at about $95 \mathrm{Ma}$ when major changes in the sedimentation patterns and tectonics were occurring. Basin subsidence and sedimentation were ending in all of the active basins at this time, and andesitic volcanogenic sedimentation was ending in Queensland and the Bass Strait regions. Also, at about $95 \mathrm{Ma}$ the eastern plate margin was changing from convergent in the north and oblique-slip in the south to back-arc extensional with sea-floor spreading (see above).

\section{METHODOLOGY}

\section{Data and isopach maps}

Interpretive palaeogeographical maps and raw sediment data maps presented in the Cretaceous Paleogeographic Maps (BMR Palcogeographic Group, 1990) were used to construct sediment isopach maps for 11 time intervals ranging in length from 4 to $12 \mathrm{Myr}$. Palacogeographical maps are interpretations of the depositional environments occurring during each interval. Multiple marine, coastal and terrigenous environments are mapped. The data maps delineate the extent of outcrop and locations of data points, primarily bore holes, with information on unit thickness and generalized lithology. A total of 343 data points are given for the Cretaceous, but not all of these data points contain information for each interval.

Isopach maps of marine sediments were constructed using constraints on the areas of deposition from the palaeogeographical maps. Regions interpreted as erosional or unclassified terrigenous environments were defined as areas of non-deposition. These areas were digitized and gridded, with sediment thickness values from the data maps, on to a $5^{\prime} \times 5^{\prime}$ mesh. A surface gridding algorithm employing a minimum curvature solution was applied to the mesh to evaluate unassigncd grid nodes (Smith \& Wessel, 1990; Wessel \& Smith, 1991). Figure 3 shows the resulting total sediment isopach for the Cretaceous, and locations of the data points from which the isopachs were generated. Because of the non-uniform distribution of data, only deposition in the Eromanga/Surat Basins, in areas along the north-west coast, and in the Otway Basin are well resolved. The sparse data from the Cedura depocentre

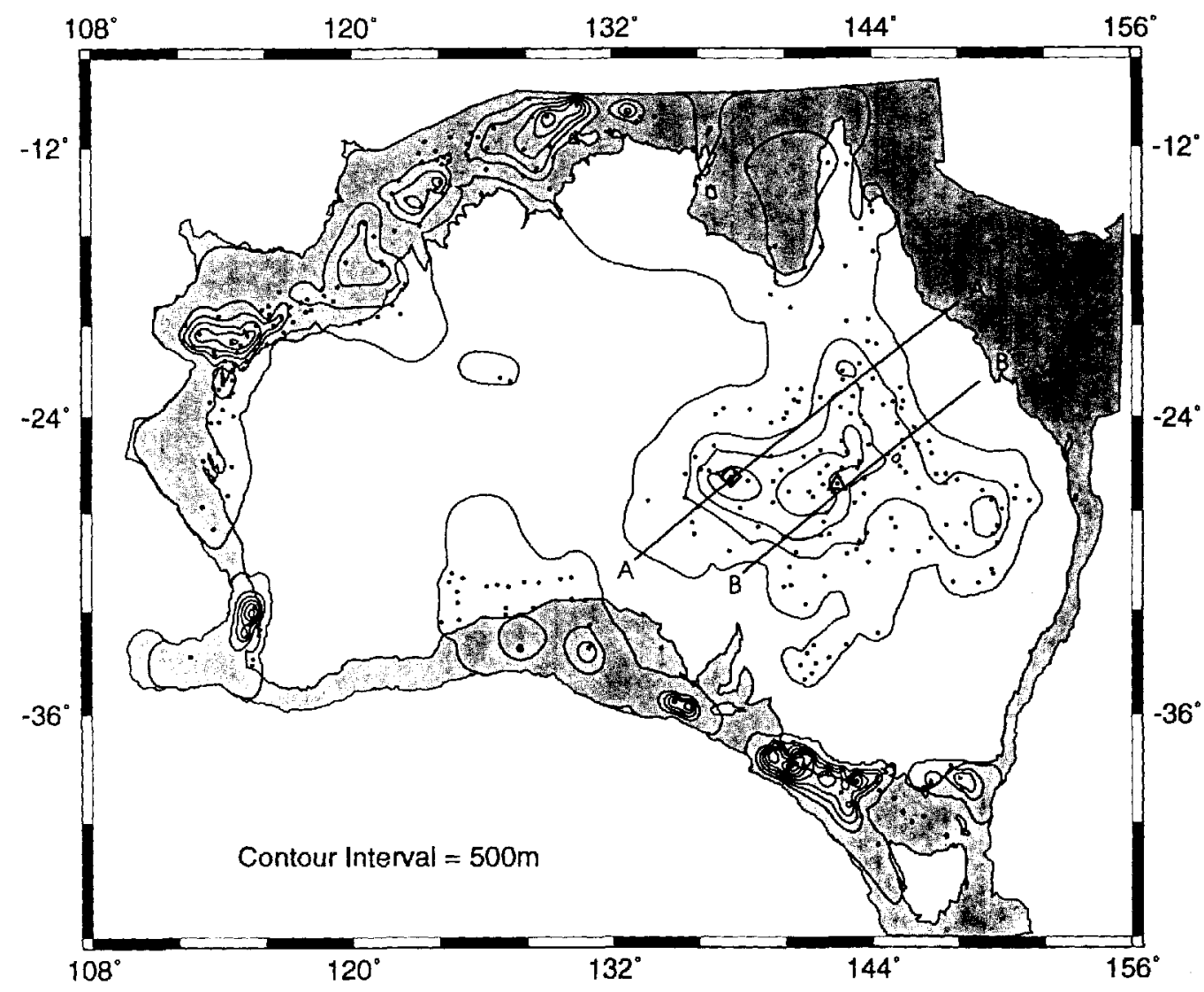

Fig. 3. L.ocation map of data points used to construct Cretaceous isopach maps. 'Total sediment isopachs $(\mathrm{CI}=500 \mathrm{~m})$ are for the entire Cretaceous. Locations of the Walkandi 1 and Wareena 1 wclls are shown by the diamond and triangle, respectively. Lines $A-A^{\prime}$ and $B-B^{\prime}$ locate sections in Fig. 10. The arcas currently below sea level are shaded. 
and South Australia represent a large source of error along the southern margin. The magnitude of this error can be estimated for the Ceduna depocentre using total sediment thicknesses obtained from seismic reflection work. Fraser \& Tilbury (1979) estimate that the Cretaceous sediments in this area reach a maximum thickness of $12 \mathrm{~km}$, while the well data suggest a maximum thickness of less than $2 \mathrm{~km}$. This is an extreme case that is not repeated elsewhere. The Ceduna depocentre is thought to be one of the largest depocentres for Cretaceous sediments, yet it remains relatively undrilled. Part of the reason for this lack of drilling data is that much of the sediment pile exists beyond the continental margin in deep water. Deep water areas have been excluded from our study to minimize the effect of this lack of data on our study.

\section{Backstripping}

Before estimates of vertical motion can be made, subsidence due to sediment loading and eustasy have to be accounted for. The sequential removal of sediment loads backwards through time is commonly referred to as backstripping. The backstripping technique of Steckler \& Watts (1978) additionally corrects for palaeowater depth and sea-level change and can be modified to account for sediment compaction. This approach to backstripping is more appropriate to individual well analysis where well-resolved lithology and geophysical data allow estimates of compaction parameters and palaeowater depths. Our large-scale planform approach was not conducive to this method. We corrected only for subsidence due to sediment loading using an Airy model of isostatic compensation. Eustatic variation in sea-level was accounted for separately.

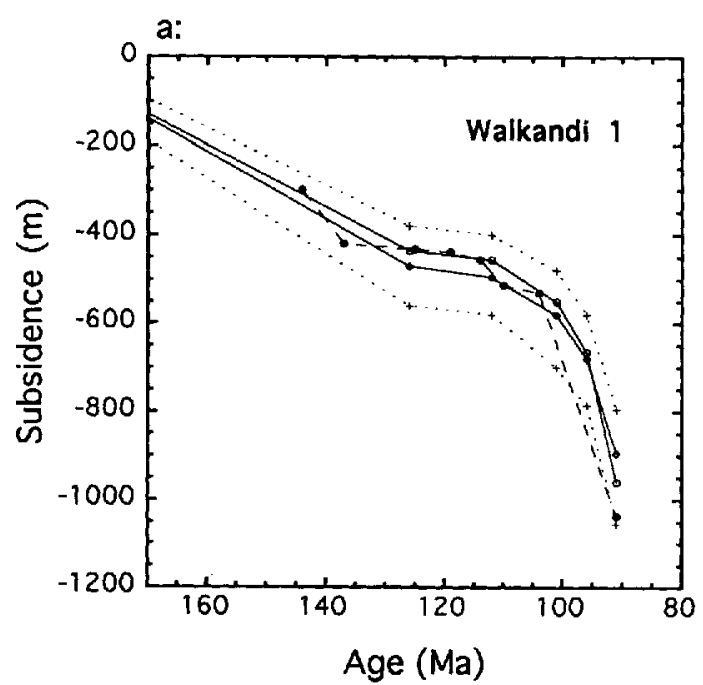

The change in surface elevation $(\Delta H)$ of a point after removal of a column of sediment is given by $\Delta H=$ $t \cdot\left(\rho_{\mathrm{m}}-\rho_{\mathrm{s}}\right) /\left(\rho_{\mathrm{m}}-\rho_{\mathrm{w}}\right)$ where $t$ is the thickness of the sediment being removed, $\rho_{\mathrm{s}}$ is the density of the sediment, $\rho_{w}$ is the density of water and $\rho_{m}$ is the density of the underlying mantle. This transformation was applied to the gridded isopach data sets and the resulting elevation corrections were applied to the topography. We used the $5^{\prime}$ gridded topography of Australia from the ETOP05 DEM. The Airy isostatic compensation model, as opposed to the unloading of an elastic plate, which was investigated by Gallagher \& Lambeck (1989) in the Eromanga Basin, was shown to be adequate when applied over length scales greater than $200-600 \mathrm{~km}$. Error due to neglect of palaeowater depth and sediment compaction in our analysis was estimated by comparing our subsidence curves and published subsidence curves for the same wells (Figs 3 and 4). The Cretaceous section of the Eromanga Basin is made up of sandstones, siltstones, mudstones and minor amounts of limestone (Exon \& Senior, 1976). The large amount of compaction of the shales, which we have not accounted for, will lead to an underestimate of the amount of tectonic subsidence. However, the Wareena 1 well (Fig. $4 a)$ is representative of the close agreement between our subsidence calculations and those of Gallagher (1990; Gallagher \& Lambeck, 1989) who did take into account lithology-specific decompaction. Walkandi 1 (Fig. 4b) is an extreme example showing the divergence between our two methods; some of the apparent discrepancy is due to different length intervals used in defining the subsidence curves allowing for shorter scale variation. Generally, the differences between simple Airy unloading of the present-day sediment thickness data and full backstripping is small and will not be significant in our analysis.

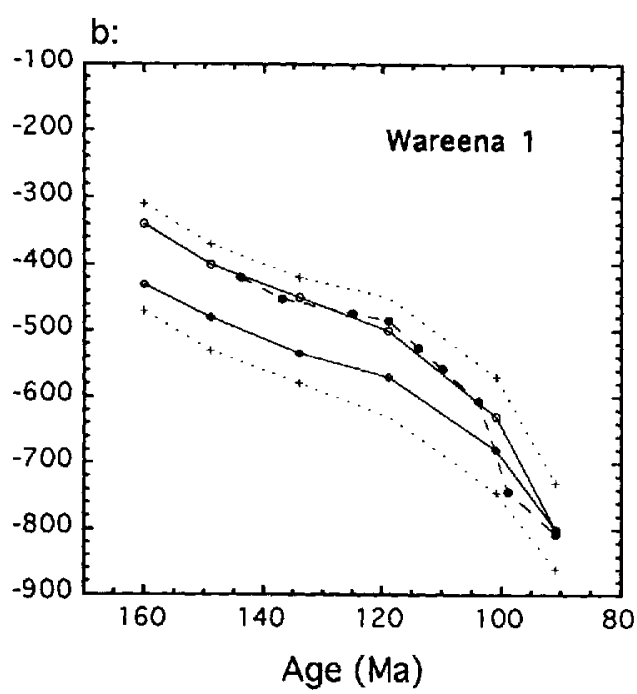

Fig. 4. Basement subsidence curves for two wells in the Eromanga Basin. The dashed lines are the bascment subsidence curves calculated in this paper. These are compared with basement subsidence curves taking into account the influence of porosity reduction by compaction (lower solid line) and cementation (upper solid line). These data are taken from (a) Gallagher \& Lambeck (1989) and (b) Gallagher (1990). In the interests of clarity, the error bars of Gallagher's original plots have been simplified such that the dotted curves define the upper and lower limits of the error shown on his curves. 


\section{Eustatic sea-level change}

In order to model epeirogeny and tectonic motion from inundation curves, a well-resolved eustatic curve and an understanding of the causes of apparent sea-level change are essential. Eustatic change in sea-level is one which is globally uniform. Difficulty arises in determining eustasy because we lack an absolute sea-level datum (Sahagian $\&$ Watts, 1991). The best we can do, thereforc, is measure sea-level relative to its present-day value. Many techniques have been employed to do this, but most require an estimate of tectonic motion.

The most widely known method for estimating sea-level change is the analysis of passive margins by seismic and sequence stratigraphy (Vail et al., 1977; Haq et al., 1987). This technique uses a form of backstripping which estimates subsidence due to both sediment loading and thermal subsidence (Steckler \& Watts, 1978). The ability of this technique to extract a small sea-level change while estimating a large amount of tectonic subsidence has been questioned (Christie-Blick et al., 1990). Others (Hallam, 1977; Bond \& Kominz, 1991; Sahagian \& Holland, 1991) have attempted to remove the inherent uncertainty in estimating subsidence by looking at large areas of flat-lying sediments on cratonic platforms under the assumption that these platforms have undergone little, if any, vertical motion contemporaneous with, or following, sediment deposition. If this assumption is correct, estimates of relative sea-level from undeformed marine sediments on stable cratons may be the most accurate we have at present. For this reason we have chosen to use the sea-level curve of Sahagian \& Jones (1993) obtained from analysis of undeformed Jurassic and Cretaceous marine sediments on the Russian Platform (Fig. 5).

The assumption that the Russian Platform has not been subject to epeirogenic motion since the Jurassic may not, however, be valid. The impact of this on our study depends on the timing of movement of the Russian Platform. Motion occurring after the end of the
Cretaceous will affect only the inferred magnitude of sea-level change during the Cenozoic. This will shift Sahagian's sea-level curve relative to present sea-level, but will not affect their estimates of relative sea-level change during the Cretaceous. The net effect would be to shift our estimates of epeirogeny an equal amount, leaving the shape of the Cretaceous portion of the curve intact. If the Russian Platform was undergoing epeirogeny during the Cretaceous, however, the effect on our results would be difficult to quantify. The inferred changes in sea-level would result from the integrated effect of true custasy and epeirogeny. This would result in our estimate of epeirogenic motion being a measure of Australian motion relative to both the motion of the Russian Platform and eustasy.

\section{Estimation of dynamic motion}

Estimates of dynamic motion of Australia were produced by modelling the pattern of marine inundation obtained from the palaeogeographical reconstructions. Modelling was accomplished by backstripping sediments from current Australian topography and compensating for changes in relative sea-level. Dynamic motion was determined by the displacement needed to approximate the observed flooding.

The modelling process was identical for each time interval. Each step began with the topography of Australia and sea-level known relative to present sea-level. The thickness and arcal distribution of marine sediment deposited over the preceding time interval are also known (Fig. 6a). Once the initial model of palaeogeography is determined, sediment is backstripped, and topography adjusted for changes in sea-level, including isostatic compensation for the change in water load (Fig. 6b). In Fig. 6(a) the sea-level, relative to today, is higher prior to sediment deposition than after it. If the areal extent of sediment cover reflects the extent of flooding then a discrepancy clearly exists between

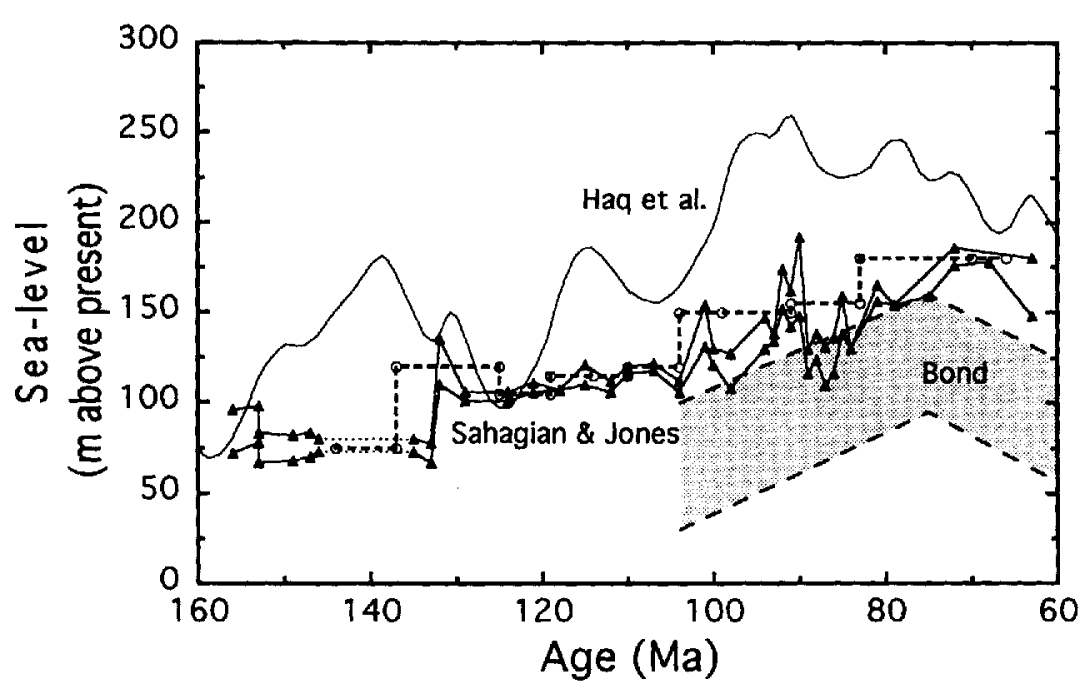

Fig. 5. A comparison of several sea-level curves. The Sahagian $\&$ Jones (1993) curve was derived from sediment analysis of the Russian platform. The curve used in this study is shown as a bold dashed line. The Haq et al. (1987) curve shows only long-term variations in sea-level. The Bond (1978) curve was constructed based on simultaneous hypsometric analysis of several continents. Both the Sahagian \& Jones and Bond curves are denoted with upper and lower bounds. 
a:

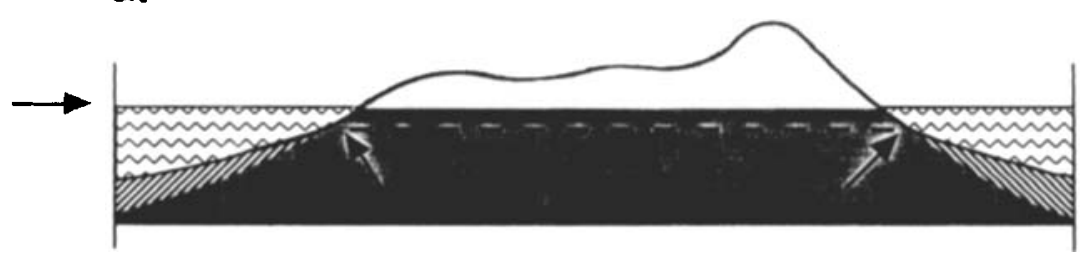

b:

Fig. 6. Cartoon of the method used to estimate vertical motion of a continent. (a) Initial conditions with known sealevel and sediment distribution (hatched). Extent of marine sediments is indicated by dashed line. (b) Time interval prior to sediment deposition. Sea-level is higher than after sediment deposition (a). Arrow at the left of each frame is a fixed refcrence point relative to sea-level in (a) by which the relative change in continental height and sea-

leval can be measured in (b) and (c). (c) Fstimate of bulk vertical motion needed to make the modelled position of sea-level coincide with the observed position of sea-level (dashed line) from palaeogeographical reconstructions.
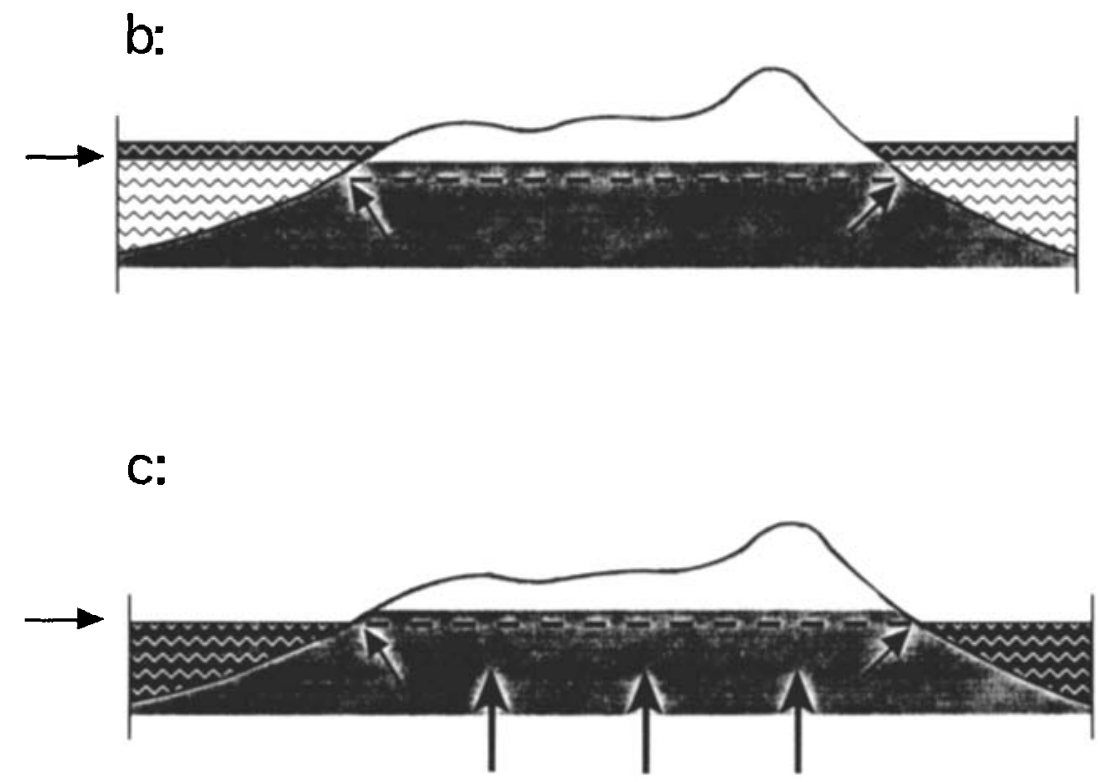

modelled and observed flooding. Sea-level relative to the continent is higher than in the initial model yet the observed flooding would predict a lower relative sea-level.

This model then allows an estimate of the uplift or subsidence needed to fit the observed flooding pattern. The vertical motion needed to bring all points that are modelled as flooded when the palaeogeographical reconstruction indicates that they were exposed, or vice versa, is determined, and takes the form of a bilinear surface. This method allows for tilting of the continent in two orthogonal directions rather than investigating only uniform vertical motion. The modelled surface can then be altered to generate a bettcr fit to the observed flooding pattern.

\section{RESULTS}

When this procedure is applied to Australia the results are dramatic. Near the end of the Cretaceous (66$70 \mathrm{Ma}$ ), sea-level was $180 \mathrm{~m}$ above present sea-level, but a smaller fraction of the continent, relative to the present day, was flooded (Fig. 7a). The model for inundation that accounts for sediment unloading and eustasy shows that flooding would have extended a large distance inland around most of the perimeter of the continent and into large portions of the east and centre of the continent. A lack of marine sediments of this age in the continental interior suggests that the bulk of the continent was exposed at the end of the Cretaceous. Raising the continent an average of $253 \mathrm{~m}$ brings the extent of modelled flooding into good agrcement with the palaeogeographical reconstruction except in the northeast where the Cenozoic opening of the Coral Sea prevents us from modelling this area because of a lack of topographical data.

An estimate of the error was obtained by perturbing the epeirogenic movement until the extent of flooding was unacceptable. This was accomplished by a simple bulk shift of the continental elevation both above and below the modelled height, allowing for independent estimates of the error in each direction. The limit of error was taken at the height where approximately $70 \%$ of the length of the outline of the reconstructed inundation was outboard (or inboard) of the outline of palaeogeographical inundation. When the model is lowered a moderate distance, significant portions of the continent are flooded, suggesting the estimate of vertical motion is conservative. It should be kept in mind that the palaeogeographical reconstructions estimate the maximum combined extent of flooding during an interval and that the maximum extent of flooding at any instant in time during the interval may not be as great as flooding represented in the palaeogeographical maps. The error bounds for the Maastrichtian, $+60 \mathrm{~m}$ and $-50 \mathrm{~m}$, are 

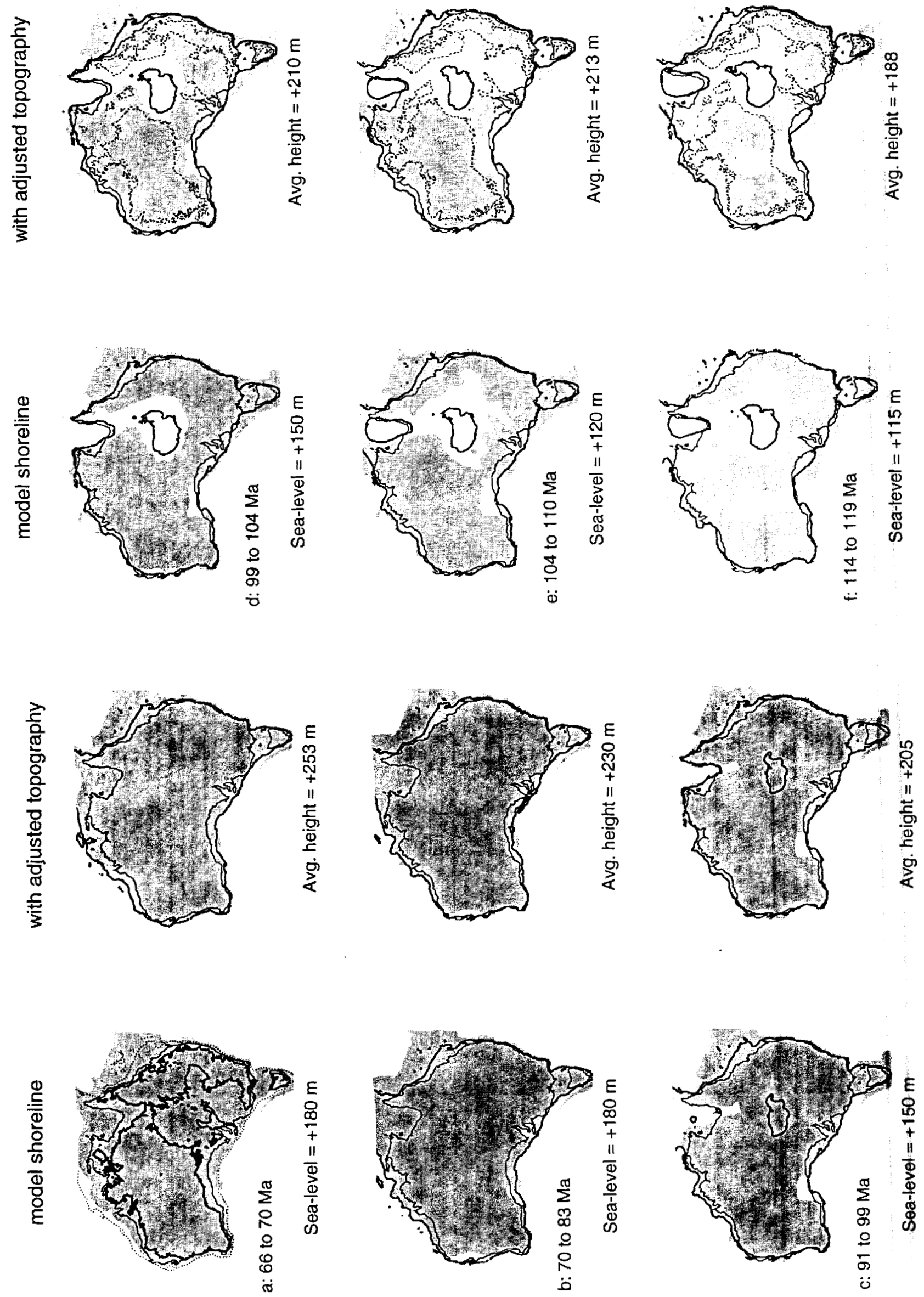


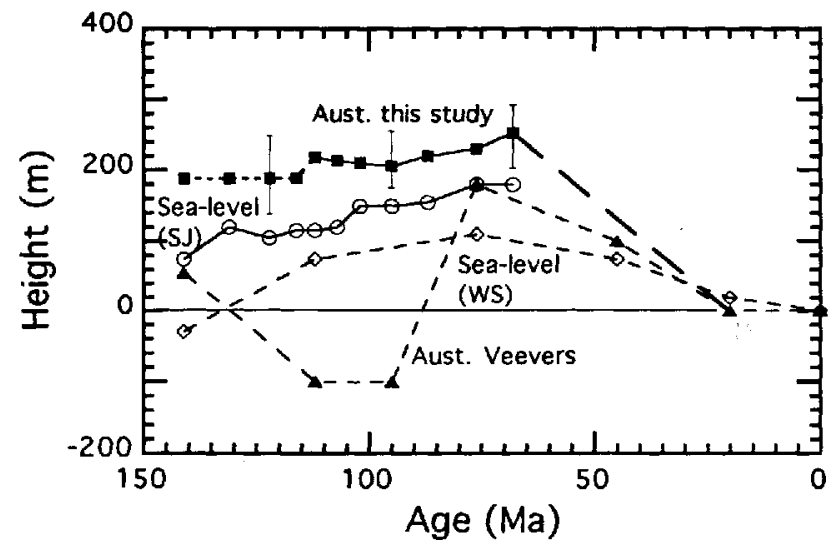

Fig. 8. Estimates of average bulk vertical continental motion for Australia derived here (solid line) compared with Veever's (1984) estimates (dashed line). The sea-level curves used in estimating vertical motions are (SJ) Sahagian \& Jones (1993) and (WS) Watts \& Steckler (1979).

shown relative to the average change in continental height applied to each interval, and relative to current sea-level (Fig. 8). The uplift modelled for cach interval is shown in Fig. 9.

During the Campanian and carly Maastrichtian, 70-83 Ma, sea-level apparently remained relatively constant (Fig. 5) while Australia appears to have been, on average, slightly lower at the beginning of the Campanian. The average uplift during this interval was about $23 \mathrm{~m}$ (Fig. 9). There was only about $10 \mathrm{~m}$ of uplift in the east, but uplift progressively increased toward the west to more than $60 \mathrm{~m}$ along the western margin. The reconstructed inundation fits most of Australia but does not resolve flooding in the Carnarvon Basin, suggesting that this area has undergone substantial local uplift since about $70 \mathrm{Ma}$ in addition to the modelled regional uplift.

The interval from 83 to $91 \mathrm{Ma}$ (not shown in Fig. 7) has good agreement between modelled inundation and reconstructed inundation. The changes in model flooding due to a sea-level $25 \mathrm{~m}$ lower than in the Campanian (Fig. 8) correlate well with the changes in flooding expected from the palaeogeographical reconstruction. Only about $10 \mathrm{~m}$ of uplift is modelled during this interval, but motion on this scale cannot be well resolved because of compound errors in the palaeogeographical reconstructions, sea-level curves and sediment isopachs used for backstripping.

The interval from 91 to $99 \mathrm{Ma}$, latest Albian and Cenomanian, shows little change in the average continental height (about $15 \mathrm{~m}$ of uplift) and little change in sea-level (about a $5 \mathrm{~m}$ rise) during the Cenomanian. The
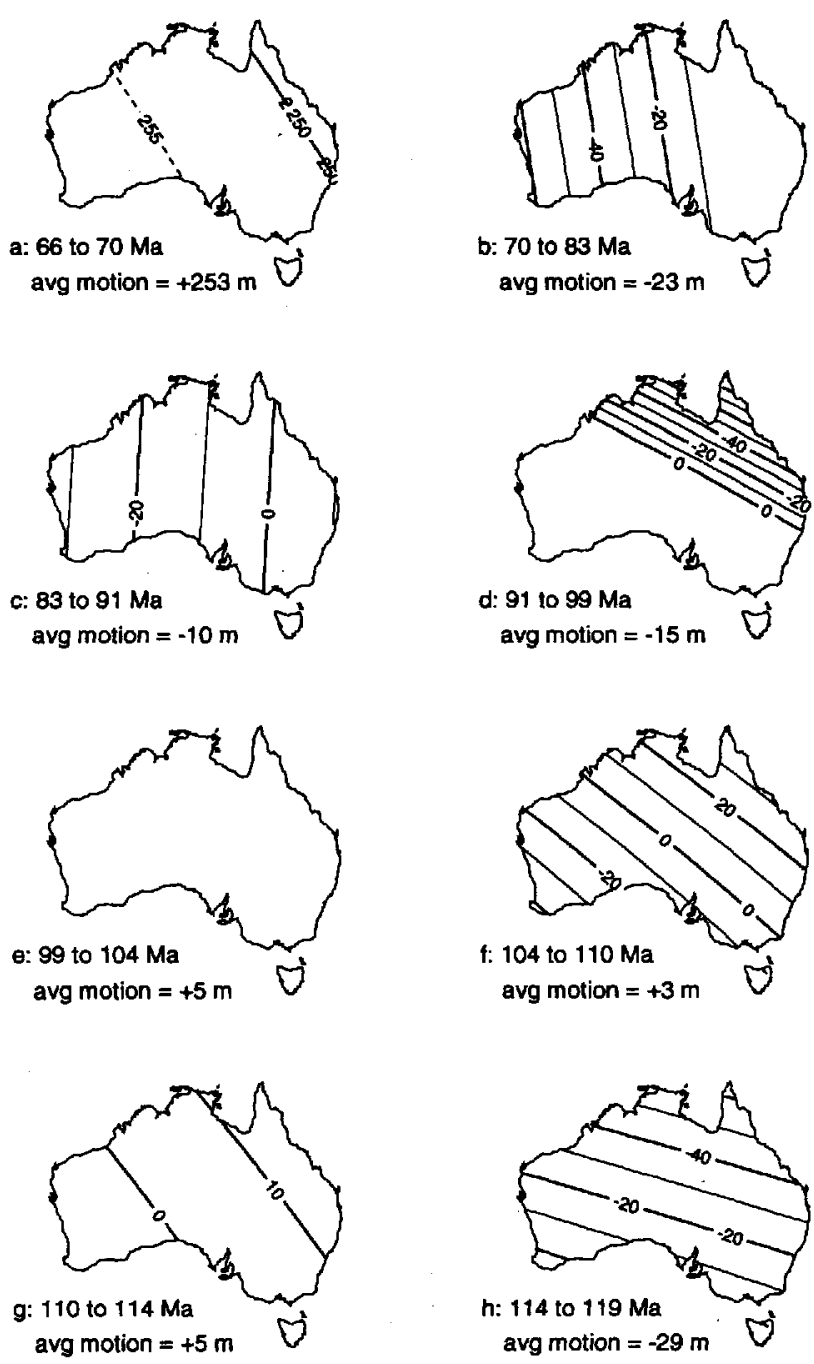

Fig. 9. Estimated vertical motion for each interval during the Cretaceous. The values in (a) are the uplift in metres of Australia relative to today. The subsidence represented in (b) is relative to the continental position in (a).

movement was not uniform (Fig. 9d). The southern and western portions of Australia appear to have been stable over this interval while the north-east third of Australia saw progressive uplift to the north-east with a maximum of about $80 \mathrm{~m}$ of uplift in the northern portion of the Carpentaria Basin. Also during the Cenomanian we see the last vestiges of inundation into the Eucla Basin which the model topographic change cannot account for. Like the Carnarvon Basin discussed above, we suggest that this area has been progressively uplifted since the Early Cretaceous.

The late Albian, about 99-104 Ma, saw the regression

Fig. 7. Models of flooding during six intervals of the Cretaceous. On all maps, the shaded area represents the exposed area interpreted from palaeogeographical reconstructions. The thick solid line shows the estimated shoreline after sediment backstripping and sea-level corrections (left), to which bulk vertical motion of the continent is then added (right). The dotted line (a) is the present-day $300-\mathrm{m}$ isobath for reference as an estimate of the current margin of the continent. The thin dashed line in (d), (e) and (f) is the $300-\mathrm{m}$ contour. 
of marine inundation from the eastern interior of Australia. When we attempted to model this flooding by bulk vertical motion of the entire continent we obtained the flooded area shown by the lightly dashed line in Fig. 7 (d), corresponding to the $300-\mathrm{m}$ contour. This line results from an epcirogenic uplift of Australia by $350 \mathrm{~m}$ over a 5-Myr interval. It is clear that flooding the Eromanga Basin region in such a simple motion would result in extensive flooding in vast regions of Australia which show no evidence of flooding. This is clearly not a valid scenario by which to explain the flooding in the eastern interior seaway; consequently, we excluded this region from our analysis of general continental motion. We have assumed that much of the flooding in the Eromanga was due to a pattern of regional subsidence on a smaller scale than could be accomplished by a simple bilinear vertical translation. We will discuss below how this may have been related to the dynamic interaction of the lithosphere with a subducting slab that may have been present along the Qucensland coast at the time. When the flooding in the Eromanga is excluded, the best fit vertical translation is only about $5 \mathrm{~m}$ of subsidence during the Cenomanian.

The middle Albian time (104-110 Ma) has a sea-level about $30 \mathrm{~m}$ lower than that in the late Albian, but the average continental height remained the same; the best fit between modelled topography and palaeogeography allows only an average of $3 \mathrm{~m}$ of subsidence over the interval. This motion was not, however, uniform; north-east Australia experienced up to about $35 \mathrm{~m}$ of subsidence during the interval while the south-west saw up to $40 \mathrm{~m}$ of uplift (Fig. 9f). During the early Albian (110-114 Ma) sea-level was $5 \mathrm{~m}$ lower and the continent appears to have been about $5 \mathrm{~m}$ higher than during the later Albian. This motion was fairly uniform, with a slight subsidence occurring in the north-east and slight uplift in the south-east along the same orientation as during the middle Albian (Fig. 9g).

The Early Cretaceous presents a complex pattern of extensive flooding during the Aptian (114-119 Ma), and very little flooding of the craton prior to this (with the exception of some flooding in the Eromanga and Surat Basins). We were unable to recreate the flooding interpreted for the Aptian (Fig. 7f). The flooding patterns from the palaeogeographical reconstructions suggest that Australia underwent a scries of rapid small-scale regional motions during this interval. Sea-level differs little from the interval before it (Fig. 5), but the amount of flooding estimated for Australia changes drastically over a 5-10-Myr interval. During the Aptian northern Australia as well as the Officer and Eucla Basins flood while the south-east portion of the continent remains exposed. 'This leads us to conclude that Australia probably underwent both Iong-wavelength motion and regional tectonic motion beyond our ability to resolve. The initiation of rifting between Australia and Antarctica may also have played a large role in flooding the Eucla and Officer Basins. If this is the case, then any estimate of motion for the preceding times is suspect. These times are presented in Fig. 8 with our curve for Australia's motion, but the estimates are poorly constrained.

\section{DISCUSSION}

\section{Cenozoic}

Our results suggest that since the end of the Cretaceous the mean elevation of Australia has dropped about $75 \mathrm{~m}$ relative to sea-level, or $255 \mathrm{~m}$ relative to its current position if sea-level was $180 \mathrm{~m}$ higher than it is today (Fig. 8). This value agrees well with estimates of Australia's motion previously made with hypsometric analysis. Veevers (1984) calculated that Australia was $180 \mathrm{~m}$ higher than today at $76 \mathrm{Ma}$, assuming sea-level was only $100 \mathrm{~m}$ above its present level. This results in a 70-m change in continental height relative to sea-level. Figure 9 shows the best fit bilinear trends that were applied to Australia during each interval. Apparently, Australia has subsided in bulk with little tilting (Fig. 9a). This corroborates the interpretations of both Bond (1978) and Veevers (1984). Since we did not carry out our analysis in discrete steps during the Cenozoic, we cannot exclude the possibility that the continent tilted, and then restored its orientation during the Cenozoic.

Further support for a large bulk motion of the continent can be found in the subsidence analysis of the Eromanga Basin (Gallagher \& Lambeck, 1989). Their models of the Eromanga, using a thermal tectonic subsidence regime, show a discrepancy between predicted and observed topographic height for the central Eromanga, with the predicted values ranging from $100 \mathrm{~m}$ to greater than $200 \mathrm{~m}$ above present values. These discrepancies would be eliminated if the continent as a whole has subsided more than $200 \mathrm{~m}$ since the end of deposition in the Eromanga Basin, as suggested by Gallagher \& Lambeck (1989).

Two possibilities which may have caused this bulk Cenozoic vertical shift of Australia are a horizontal translation of the continent from a geoid low and/or a dynamic topography high to a geoid high and/or a dynamic topography low (e.g. Gurnis, 1990). In general, both quantities must be accounted for in determining relative sea-level since the ratio of geoid to dynamic topography (e.g. admittance) determines whether scalevel is higher or lower on a geoid high (Gurnis, 1990). As seen in the maps of Hager \& Clayton (1989), there is a positive gradient in the observed long-wavelength geoid amounting to $60 \mathrm{~m}$ over the entire distance from Antarctica to Australia. Horizontal translation with respect to this geoid gradient would have lead to an apparent subsidence of Australia since differential sea-level would have risen as Australia moved northward, but the total apparent vertical motion of Australia would be a few tens of metres. 
In addition to variation in the geoid, there is a present-day observed gradient in residual topography between Antarctica and Australia as seen in the maps of Cazenave \& Lago (1991) and Pribac (1991). Residual topography is obtained by subtracting the normal thermal contraction of oceanic lithosphere (which depends only on age) from observed bathymetry as well as making corrections for sediment thickness (Crough, 1983). Globally, residual topography is generally interpreted in terms of dynamic topography: first, residual oceanic topography is in phase with the geoid at the longest wavelengths and, second, the pattern of dynamic topography predicted from spherical viscous flow models (Hager et al., 1985) is remarkably similar to observed residual topography (Gurnis, 1992a). Residual topography between Antarctica and Australia is characterized by the largest depression in mid-ocean ridge depth-the so called Antarctic-Australian discordance (Crough, 1983; Hays, 1988). Perhaps because of the prominence of the discordance in residual topography, this gradient has apparently not been described. Stacked bathymetry profiles along lines of longitude and plotted with lithospheric age (Cochran, 1986) show residual topography closer to Antarctica to be $100-400 \mathrm{~m}$ higher than residual topography just to the south of the Australian margin. Because of the discordance, it is unclear if this residual topography is better characterized as a simple ramp or function with a sharper ramp somewhere within $500 \mathrm{~km}$ of the ridge. If we assume that this residual topography is indeed dynamic and that the gradient between Antarctica and Australia is stationary with respect to a hot-spot reference frame, then from at least the end of the Cretaceous to the beginning of the Cenozoic, Australia would have been c. 100-200 m higher than today. If we consider the northward positive gradient in the geoid, in addition to the negative gradient in topography, then we would predict Australia would have fallen about $150-250 \mathrm{~m}$-remarkably consistent with the average drop in the height of Australia (Fig. 8).

This would be fundamental if the result can be corroborated with detailed work because it would allow us to link a period of observed continental epeirogeny with a known geophysical process. We suggest three avenues where further work would be particularly enlightening. First, detailed studies to establish the planform of epeirogeny during the Cenozoic in the same fashion as we have inferred motion during the Cretaceous; did Australia undergo an ephemeral tilting event? Second, detailed studies of the residual topography are needed between Australia and Antarctica, especially studies which account for the load of sea-floor sediments since these are substantial just north of the Antarctic margin. Third, three-dimensional modelling of mantle flow with both internal buoyancy and plates are needed to explore how the surface pattern of dynamic topography changes as Australia separated from Antarctica and moved northward. Clearly, an acceptable model will have to be consistent with both the flooding of Australia and the present-day residual topography.

\section{Late Cretaceous (66-91 Ma)}

East-west long-wavelength tilting characterizes the Turonian through the Campanian of Austraila. The magnitude of this change is considerably smaller than the post Late Cretaceous fall of Australia (Fig. 8). The western edge of Australia appears to have started slowly uplifting about $90 \mathrm{Ma}$, rising at a rate of about $4 \mathrm{~m} \mathrm{Myr}^{-1}$ along the west coast with decreasing uplift to the east (Fig. 9b,c). This motion continued at least until about $70 \mathrm{Ma}$ and resulted in about $90 \mathrm{~m}$ of total uplift along the west side of the continent and no resolvable motion along the east side. Palaeomagnetic data suggest that the continent was relatively stationary during this period, undergoing only a slight anticlockwise rotation (Vecvers et al., 1991). At this stage, we can provide no explicit hypothesis for this apparent tilting, except to suggest that it may be related to a change in dynamic topography or geoid.

\section{Middle Cretaceous (91-114 Ma)}

The Aptian appears to have been a relatively quiet time in terms of continent-wide vertical motions. When subsidence in the Eromanga Basin is excluded from the analysis the basic trend seen in the Late Cretaceous continues. The south-eastern portion of the continent experienced minor amounts of uplift during the interval, about $40 \mathrm{~m}$, while the north-west saw minor amounts of subsidence, about $40 \mathrm{~m}$ (Fig. $9 \mathrm{e}-\mathrm{g}$ ).

During the Cenomanian, uplift was confined to the north-east third of Australia, with the rate possibly exceeding $10 \mathrm{~m} \mathrm{Myr}^{-1}$ in the north-east tip of the continent (Fig. 9d). Palaeomagnetic data suggest that between 118 and $96 \mathrm{Ma}$ Australia's north-east coast underwent a large anticlockwise rotation (Veevers et al., 1991), during the same time the convergent regime was coming to an end after existing along the north-east coast for most of the previous $100 \mathrm{Myr}$. The termination of subduction and the rotation of the north-east corner of Australia away from an area of subduction may have allowed the area to uplift rapidly.

While Australia as a whole was relatively stable over this interval, the eastern interior portion of the continent was very active. During the late Albian and the Cenomanian the Eromanga Basin received the majority of the sediment deposited during the Cretaceous, while simultaneously undergoing a regression as the eastern interior seaway either dried up or was forced out by a sediment load that filled the basin (e.g. Gallagher \& Lambeck, 1989). Cross-section $A-A^{\prime}$ and $B-B^{\prime}$ of Fig. 3 are shown in Fig. 10. These cross-sections show the sediments deposited in the Eromanga and Surat Basins between 144 and $91 \mathrm{Ma}$. The upper surface of the 

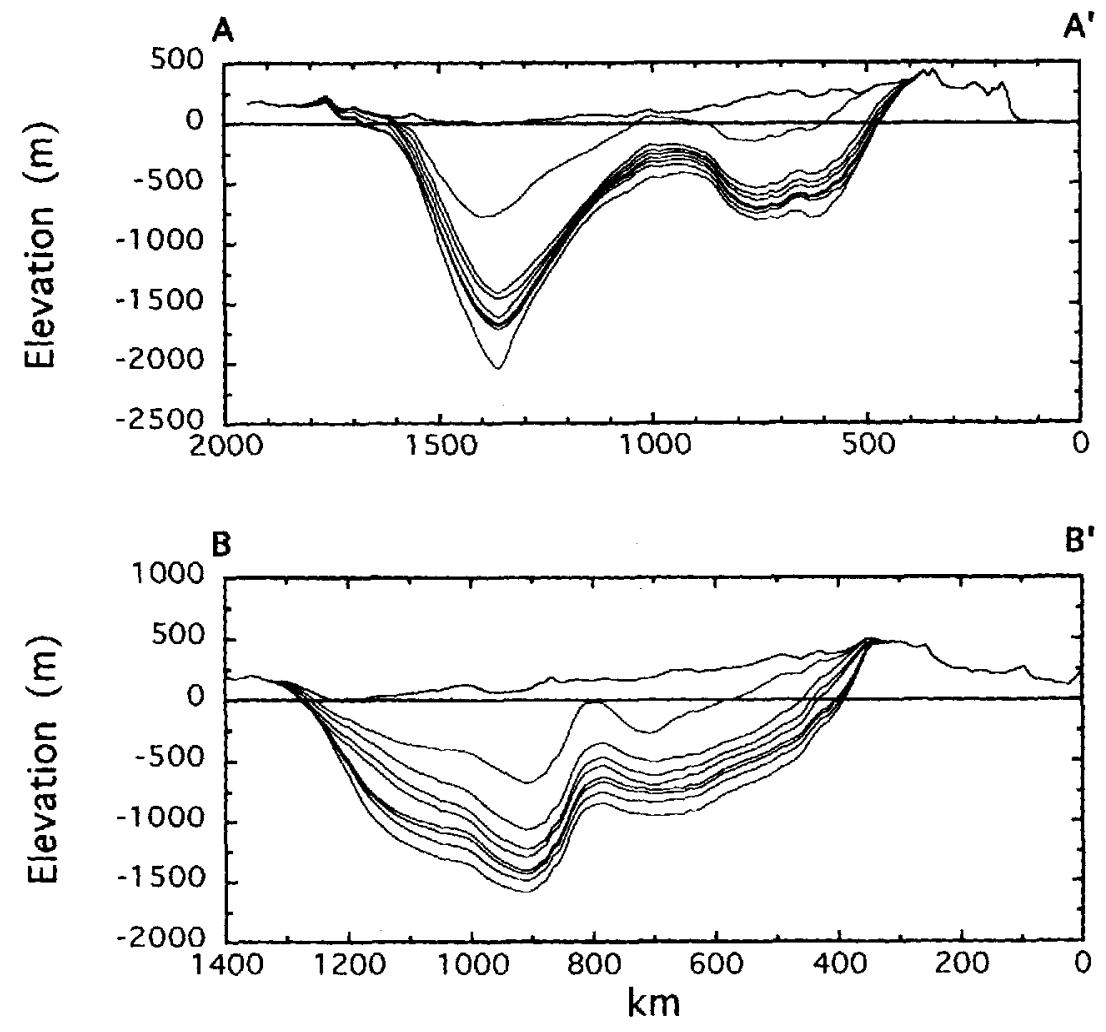

Fig. 10. Cross-sections across the Eromanga Basin. The orientation is shown in Fig. 3. The sediment packages represent the intervals outlined in Fig. 9 with the last sediment being deposited between 99 and $91 \mathrm{Ma}$. cross-sections is the present-day topography across the line of section.

Since the sediments are generally shallow marine except for those deposited during the last interval, the cross-sections of Fig. 10 imply that there has been dramatic tilting, with uplift toward the east, that occurred since the deposition of sediments in the Eromanga Basin. Furthermore, broad-scale tilting since $91 \mathrm{Ma}$ is rather small (during the interval 91-99 Ma, the maximum broad-scale modelled tilting is up toward the east and has a magnitude of about $60 \mathrm{~m}$ over about $1300 \mathrm{~km}$ ). The motion evident in the cross-sections has been largely with respect to (or in addition to) the broad-scale motion of Australia generated to satisfy the overall pattern of flooding (Fig. 7). The difference betwcen our Australian height curve (e.g. Fig. 8) and Bond's (1978) and Veever's (1984) curves shown in Fig. 1 results because we explicitly distinguish between broad-scale motion of the continent and regional subsidence and subsequent tilting within the eastern interior sea-way.

The sediment thicknesses shown in Fig. 10 are broadly similar to theoretical chronostratigraphic surfaces of a basin created by the dynamic topography generated by an evolving subducted slab (Gurnis, 1992b). During the time when these Eromanga sediments were deposited, there was a converging margin (Fig. 2) perpendicular to the orientation of the profiles (Fig. 3). When convergence apparently ceased at $95 \mathrm{Ma}$, there was a regression within the eastern interior followed by
$500 \mathrm{~m}$ of upward tilting toward the east over a distance of $500-1000 \mathrm{~km}$. Theoretical slab models show that when the dip of a subducted slab shallows, a basin $500-1000 \mathrm{~km}$ can form and that if subduction terminates (i.e. the slab falls into the deeper mantle or a ridge and trench coalesce) there will be tilting upward toward the margin (e.g. fig. 2 in Gurnis 1992b; Mitrovica et al., 1989).

\section{Summary}

We suggest that when spreading between Australia and Antarctica started, the dip of the slab associated with the north-eastern converging margin decreased and led to gentle subsidence of the Eromanga and the castern interior. This was during a time when Australia was elevated about $250 \mathrm{~m}$ from its present height. When spreading increased at about $100 \mathrm{Ma}$, subsidence in the Eromanga quickened (e.g. Gallagher \& Lambeck, 1989) and then as subduction ceased the eastern interior tilted upward toward the east (e.g. Fig. 10). The entire continent remained relatively stable throughout this time. As Australia continued to move northward, it descended from a broad-scale dynamic topography high and geoid low and subsided in bulk (e.g. with little cumulative tilt) by about $250 \mathrm{~m}$. In summary, the vertical motion of Australia has a broad-scale component and a regional eastern interior component and we speculate that each of these components was related to different scales of dynamic topography. 


\section{ACKNOWLEDGEMENTS}

Thanks go to Bernie Coakley for help with the GMT program and to Gerard Bond, Coakley, Kerry Gallagher and Bruce Wilkinson for helpful comments on the manuscript. Funded by the David and Lucile Packard Foundation, NSF grant EAR-8957164, and the Petroleum Research Fund.

\section{REFERENCES}

BMR Paleoglographic Group (1990) Cretaceous Paleogeographic Maps Record 1990/30 Paleogeographic Series 14, Bureau of Mineral Resources, Canberra.

BOND, G. (1978) Speculations on real sea-level changes and vertical motions of continents at selected times in the Cretaceous and Tertiary Periods. Geology, 6, 247-250.

Bonv, G. C. (1979) Evidence for some uplifts of large magnitudes in continental platforms. Tectonophysics, 61, 285-305.

Bond, G. C. \& Kominz, M. A. (1991) Disentangling middle Paleozoic sea level and tectonic events in cratonic margins and cratonic basins of North America. 7. geophys. Res., 96, $6619-6639$.

Cazinave, A. \& Lago, B. (1991) Long-wavelength topography, seafloor subsidence and flattening. Geophys. Res. Lett., 18, 1257-1260.

Christie-Bi.ick, N., Mountain, G. S. \& Mit.l.fr, K. G. (1990) Seismic stratigraphic record of sea-level change. In: Sea-level Change (Ed. by R. R. Revelle), pp. 161-140. National Academy Press, Washington 1:250 000 sheet area, Queensland. Bureau of Mineral Resources, Australia, Report 144.

Clarke, D. E., Paine, A. G. L. \& Jensen, A. R. (1971) Geology of the Prosperline 1:250,000 sheet area, Queensland. Aust. Bur. Miner. Resour., Geol. Geophys. Rep., 144.

Cochran, J. R. (1986) Variations in subsidence rates along intermediate and fast spreading mid-ocean ridges. Geophys. 7. $R$, astron. Soc., 87, 421-454.

Crough, S. T. (1983) Hot spot swells. Ann. Rev. Earth planet. Sci., 11, 165-193.

Exon, N. F. \& SENior, B. R. (1976) The Cretaceous of the Eromanga and Surat Basins. BMR 7. Aust. Geol. Geophys., $1,33-50$.

Falvey, D. A. \& Mutte:R, J. C. (1981) Regional plate tectonics and the evolution of Australia's passive continental margins. BMR 7. Aust. Geol. Geophys., 6, 1-29.

Frase:R, A. R. \& Tilbury, L. A. (1979) Structure and stratigraphy of the Ceduna Terrace region, Great Australian Bight Basin. APEA 7., 19, 53-65.

Gal.t.agher, K. (1990) Permian to Cretaceous subsidence history along the Eromanga-Brisbane Geoscience Transect. In: Bulletin 232, The Eromanga-Brisbane Geoscience Transect: A Guide to Basin Development Across Phanerozoic Australia in Southern Queensland (Ed. by D. M. Finlayson), pp. 133-151. Bureau of Mineral Resources, Geology and Geophysics, Canberra.

Gai.taghfr, K. \& Lambeck, K. (1989) Subsidence, sedimentation and sea-level changes in the Eromanga Basin, Australia. Basin Res., 2, 115-131.

Gurvis, M. (1990) Bounds on global dynamic topography from
Phanerozoic flooding of continental platforms. Nature, 344, $754-756$.

Gurnis, M. (1992a) Long-term controls on eustatic and epeirogenic motions by mantle convection. GSA Today, 2, 141-157.

GurNis, M. (1992b) Rapid continental subsidence following the initiation and evolution of subduction. Science, 255, 1556-1558.

Hager, B. H. \& Clayton, R. W. (1989) Constraints on the structure of mantle convection using seismic observations, flow models, and the geoid. In: Mantle Convection (Ed. by R. W. Peltier), pp. 657-763. Gordon and Breach Science Publishers, New York.

Hager, B. H., Clayton, R. W., Richards, M. A., Comer, R. P. \& Dziewonski, A. M. (1985) Lower mantle heterogeneity, dynamic topography and the geoid. Nature, $313,541-545$.

Hallam, A. (1977) Secular changes in marine inundation of USSR and North America through the Phanerozoic. Nature, 269, 769-772.

HaQ, B. U., Hardenbol, J. \& Vail, P. R. (1987) Chronology of fluctuating sea level since the Triassic. Science, 235, $1156-1167$.

Hays, D. E. (1988) Age-depth relationships and depth anomalics in the southeast Indian ocean and South Atlantic Ocean. 7. geophys. Res., 93, 2937-2954.

Jones, J. G. \& Veevers, J. J. (1983) A Cainozoic history of Australia's southeast highlands. 7. geol. Soc. Australia, 29, $1-12$.

Mitrovica, J. X., Beaumont, C. \& Jarvis, G. T. (1989) Tilting of continental interiors by the dynamical effects of subduction. Tectonics, 8, 1079-1094.

Pribac, F. (1991) Superspells due to mantle convection. PhD thesis, Australian National University, Canberra.

Richards, M. A. \& HAGER, B. H. (1984) Geoid anomalies in a dynamic Earth. 7. geophys. Res., 89, 5987-6002.

Sahagian, D. L. \& Holland, S. M. (1991) Eustatic sea-level curve based on a stable frame of reference: preliminary results. Geology, 19, 1209-1212.

SAHAgIan, D. \& Jones, M. (1993) Quantified middle-Jurassic to Paleocenc eustatic variations based on Russian platform stratigraphy: stage level resolution. Bull. geol. Soc. Am., $105,1109-1118$.

Sahagian, D. L. \& WatTs, A. B. (1991) Introduction to the special section on measurement, causes, and consequences of long-term sea level change. 7. geophys. Res., 96, $6585-6589$.

SMith, W. H. \& Wessel, P. (1990) Gridding with continuous curvature splines in tension. Geophysics, 55, 293-305.

Steckler, M. \& WaTrs, A. B. (1978) Subsidence of the Atlantic-type continental margin off New York. Earth planet. Sci. Jett., 41, 1-13.

Stephenson, P. J. \& Lambeck, K. (1985) Erosion-isostatic rebound models for uplift an application to south-eastern Australia. Geophys. 7. R. astron. Soc., 82, 31-55.

Struckmeyer, H. I. M. \& Brown, P. J. (1990) Australian Sealevel Curves part 1: Australian Inundation Curves, BMR Record 1990/11. Bureau of Mineral Resources, Canberra.

Turcotre, D. L. \& SchubreT, G. (1982) GEOD YNAMICS Applications of Continuum Physics to Geological Problems. John Wiley \& Sons, New York.

Vait, P. R., Mitchum Jr, R. M., Todd, R. G., Widmier, J. M., Thompson, S., Songree, J. B., BubB, J. N. \& 
HATL,H.LD, W. G. (1977) Seismic stratigraphy and global changes in sea level. AAPG Mem., 26, 49-212.

Vilitirs, J. J. (Ed.) (1984) Phanerozoic Earth History of Australia. Clarendon Press, Oxford.

Vefvers, J. J., Powfli, C. MCA. \& Roots, S. R. (1991) Reviews of seafloor spreading around Australia. I. Synthesis of the patterns of spreading. Aust. 7. Earth Sci., 38, 373-389.

WaTrs, A. B. \& Steckirs, M. S. (1979) Subsidence and eustasy at the continent margin of eastern North America. In: Deep Drilling Results in the Atlantic Ocean: Continental
Margins and Paleoenvironment (Ed. by M. Talwani, W. Hays \& W. B. F. Rуал), pp. 218-234. AGU, Maurice Ewing Series, 3. Washington, DC.

Whicman, P. (1987) Fastern Highlands of Australia; their uplift and erosion. BMR 7. Aust. Geol. Geophys., 10, $277-286$.

Wessfi, P. \& S Siтh, W. H. F. (1991) Free software helps map and display data. EOS Trans., AGU72, 441.

Received 1 Octuber 1993; revision accepted 9 fune 1994. 